\title{
19. MAGNETIC FABRIC ANALYSIS OF SEDIMENTS FROM THE CÔTE D'IVOIRE-GHANA TRANSFORM MARGIN ${ }^{1}$
}

\author{
Sumito Morita ${ }^{2}$ and Asahiko Taira ${ }^{2}$
}

\begin{abstract}
Anisotropy of magnetic susceptibility analysis was performed to determine the type of magnetic fabric, variation with lithostratigraphy, structural geology, and physical properties of the fine-grained sediments cored at the Côte d'Ivoire-Ghana Transform Margin during Ocean Drilling Program Leg 159. Results show three types of magnetic fabric: Type 1 is a spheric ellipsoid, which has a low degree of magnetic anisotropy; Type 2 is an oblate ellipsoid, which has a positive $T$ value with a high degree of anisotropy; and Type 3 is a prolate ellipsoid, which has a negative $T$ value with a high degree of anisotropy. An unconformity that occurred between the upper Albian and lower Turonian separates Type 1 from Type 2. Samples exhibiting Type 1 fabric retain the original sedimentary fabric, and Types 2 and 3 reflect modification resulting from syntransform deformation from the initiation of the Atlantic during the Albian to early Turonian. Type 3 sediments have a vertical magnetic lineation, which is controlled by secondary mineralized and vertically aligned siderite grains. The secondary mineralization of siderite may suggest that a horizontal compressional contraction occurred in the latest Albian to early Turonian during the time of uplift of the Côte d'Ivoire-Ghana Marginal Ridge at the end of the Syntransform Basin Stage. The disordered stratigraphic occurrence of magnetic fabric types may indicate tectonic slicing of the sequence with varying degrees of deformation.
\end{abstract}

\section{INTRODUCTION}

Continental transform margins commonly produce a marginal ridge by interplate shearing along the transform fault. Such formations include the Newfoundland Ridge (Grant, 1977), the Ivory Coast-Ghana margin (Mascle and Blarez, 1987), the Oman margin (Barton et al., 1990), and the Exmouth Plateau (Lorenzo et al., 1991). The marginal ridges result from a strike-slip shearing along the transform seafloor spreading direction. During Ocean Drilling Program Leg 159 several holes were drilled into the Côte d'Ivoire-Ghana Transform Marginal Ridge in the eastern equatorial Atlantic (Fig. 1) to investigate the tectono-sedimentary evolution of a continental transform margin related to the opening of the Atlantic Ocean (Mascle, Lohmann, Clift, et al., 1996). From four drill sites, Sites 959962, researchers traced tectonic deformation and sedimentation on the Côte d'Ivoire-Ghana Transform. Onboard analysis showed that lithologic units recovered could be divided into two main sequences separated by a major Cretaceous (uppermost Albian to lower Turonian) unconformity. The sequence below the unconformity is composed of siliciclastic sediments and is severely deformed; both compressional and extensional structures (slickensides, reverse faults, and normal fractures) are present. The lower sequence, thus, was interpreted as a syntransform sequence overlain by a post-transform cover sequence.

In this study, to further investigate the structural style observed within the syntransform sequence, we used anisotropy of magnetic susceptibility (AMS) analysis. In conjunction with AMS analysis, Xray computed tomography (CT) scan, thin-section observation, and $\mathrm{X}$-ray diffraction (XRD) analyses were performed. The main purpose of this study was to detect microtectonic deformation of sediments during the transform margin evolution as magnetic fabric and to constrain the timing of the deformation. The authors focus on the varia-

${ }^{1}$ Mascle, J., Lohmann, G.P., and Moullade, M. (Eds.), 1998. Proc. ODP, Sci. Results, 159: College Station, TX (Ocean Drilling Program).

${ }^{2}$ Ocean Research Institute, University of Tokyo, 1-15-1, Minami-dai, Nakano-ku, Tokyo 164, Japan. moritas@ ori.u-tokyo.ac.jp tions in the magnetic anisotropy of pre-Turonian sediments at Sites 959 and 960, and discuss the relation of its fabric to lithostratigraphy, structural geology, and physical properties.

AMS analysis is an accurate and reliable technique to determine the magnetic fabric of rocks. AMS provides shape characteristics and orientations of magnetic susceptibility ellipsoids, which are important to the study of the rock formation and its subsequent deformation. Consequently, the method can be applied to the field of structural geology and has been used to investigate the strain pattern in rock deformation (Kligfield et al., 1977; Borradaile and Tarling, 1981; Borradaile, 1988; Sagnotti and Speranza, 1993; Sagnotti et al., 1994).

This study also uses CT scan analysis to investigate the density of sediments (e.g., Anderson et al., 1988; Soh et al., 1993; Ashi, 1995). The image of X-ray CT scanning can be obtained by mathematical reconstruction of penetrated X-ray intensity, with its attenuation coefficients calculated from absorption or scattering in objects (Iwai, 1979), which provides high-resolution density information. This makes it possible to search for a heterogeneous block inside the matrix without cutting or causing other disturbance. Furthermore, the CT scan can examine the density of a focused portion on a crosssectional image so that the density of a preserved block within a drilling-disturbed core can be investigated.

\section{GEOLOGICAL FRAMEWORK OF SITES 959 AND 960}

Continental transform margins in the South Atlantic originally resulted from offsets of the fracture zone at the initiation of the ocean between 140 and $80 \mathrm{Ma}$ (Le Pichon and Hayes, 1971). From the initiation of the Atlantic, the Côte d'Ivoire-Ghana Transform Margin, one of several transform margins, was sheared along the seafloor spreading direction until it passed a hot ridge on the other side of the transform faults, and subsequently underwent an isostatic adjustment between the continental and oceanic lithospheres by a thermal effect (Mascle and Blarez, 1987). The Côte d'Ivoire-Ghana Transform Margin has a very steep and linear continental slope, which extends seaward in an elongated marginal ridge. The marginal ridge in the Côte d'Ivoire-Ghana Transform Margin also originated from strike- 
A

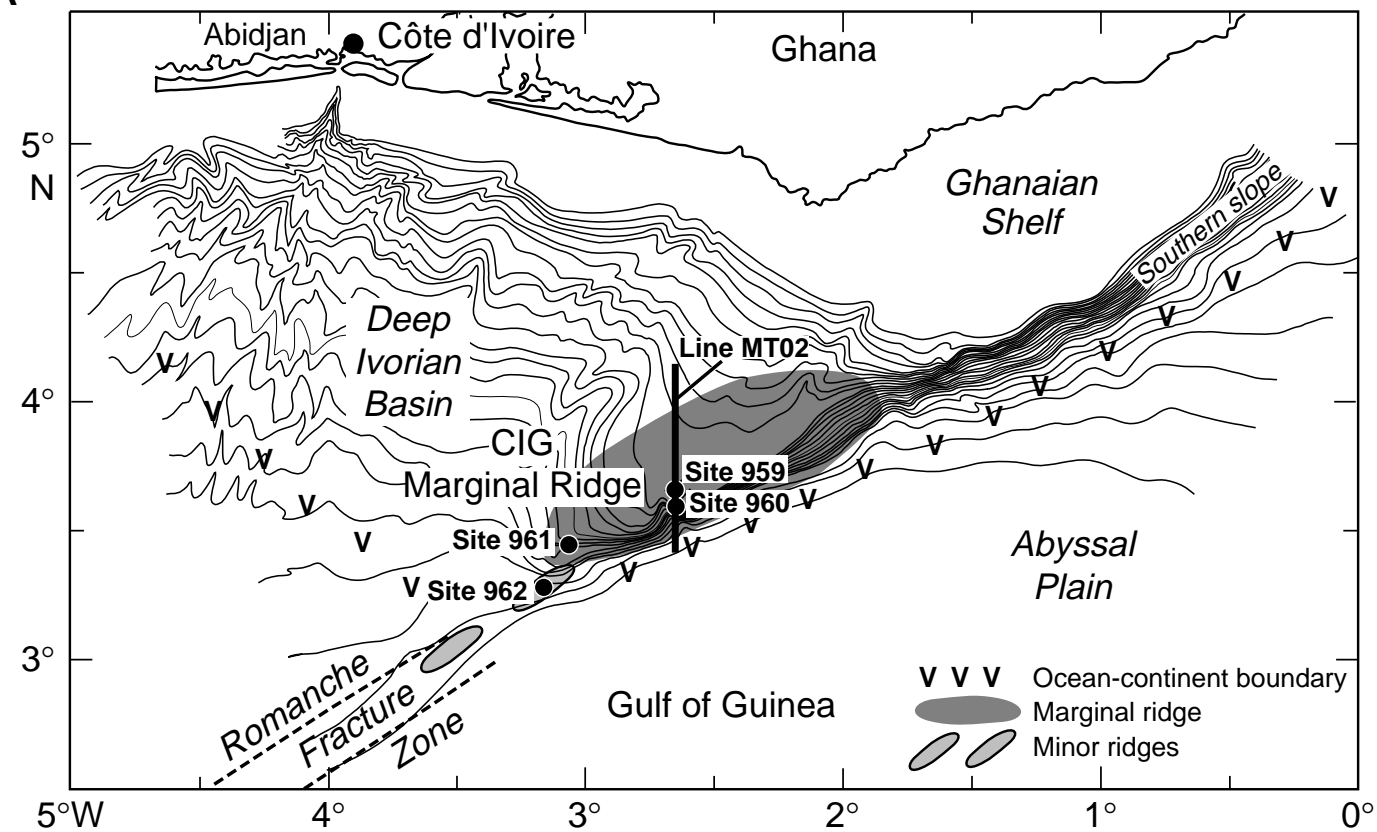

B

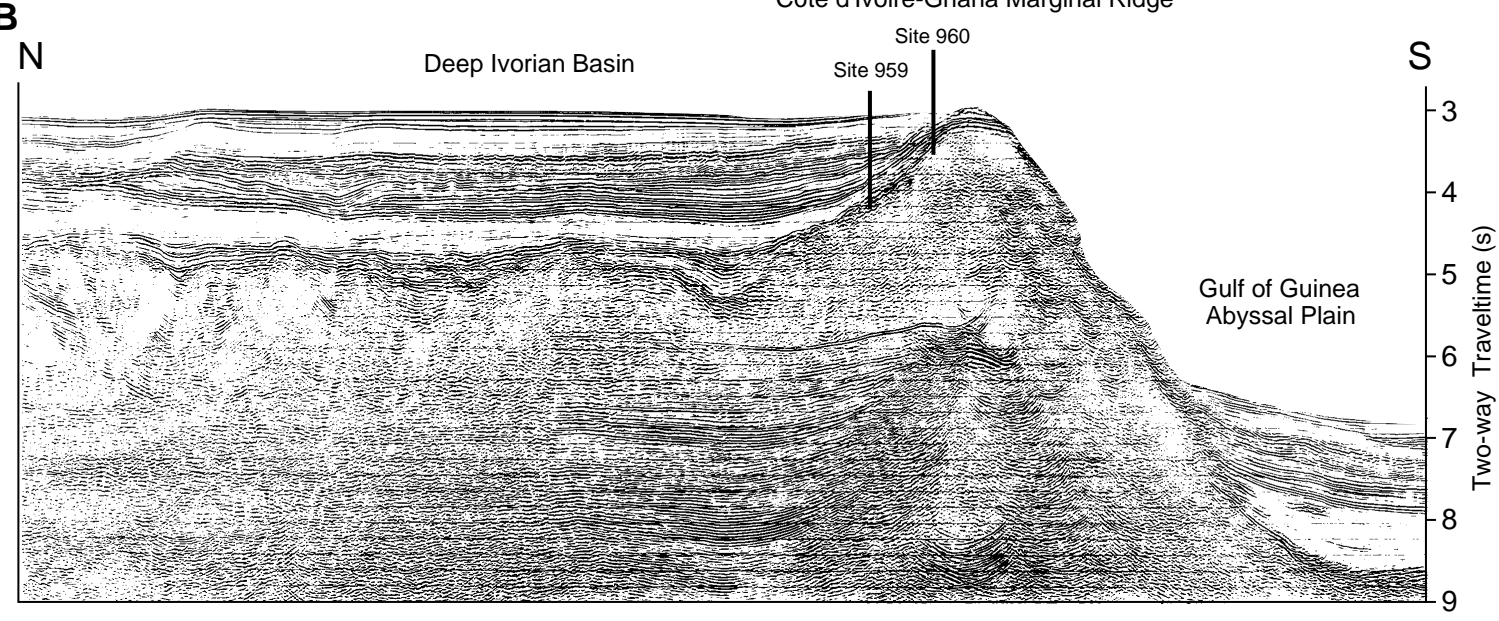

Migrated Line MT02

Figure 1. Location of Sites 959 and 960. A. Bathymetric map of the survey area of Leg 159 at the Côte d'Ivoire-Ghana Transform Margin. B. Migrated multichannel seismic cross section at Line MT02 (from Mascle, Lohmann, Clift, et al., 1996).

slip shearing (Mascle and Blarez, 1987). The ridge represents a transform boundary along the Romanche Fracture Zone between stretched continental crust (the Deep Ivorian Basin) and the Gulf of Guinea (Fig. 1).

All four Leg 159 sites are located on the Côte d'Ivoire-Ghana Transform Marginal Ridge (Fig. 1). The transform margin history is best recorded in the spatial and stratigraphic variation of sediments cored at Sites 959 and 960 (Mascle, Lohmann, Clift, et al., 1996). Hence, data from mainly Sites 959 and 960 are used in this study.

There is a large difference in the porosity of Cretaceous and Cenozoic rocks at Site 960, and similar characteristics are seen at Sites 961 and 962 (Mascle, Lohmann, Clift, et al., 1996). A notable break in porosity at $750 \mathrm{mbsf}$ at Site 959 correlates with a break in degree of deformation. Above this level, the frequency of normal faulting and veining decreases visibly. These changes of porosity and deformation may represent the end of rapid thermal subsidence and col- lapse of the continental margin in the Passive Margin Stage, following the passage of the oceanic spreading center along the margin.

The sediments cored at both sites best represent the geological history in the tectonic evolution and sedimentation on the transform margin. As a result, three principal stages have been identified in this paleoenvironmental setting: (1) the Intracontinental to Syntransform Basin Stage, (2) the Marginal Ridge Emergence Stage, and (3) the Passive Margin Stage (Mascle, Lohmann, Clift, et al., 1996).

The sedimentary sequence of the Intracontinental to Syntransform Basin Stage is characterized by a progression from the lacustrine sediments in the intracontinental phase to the mixed siliciclastic and pelagic sediments in the deep-sea phase. This stage is recorded in lithologic Unit V at both Sites 959 and 960, and the earliest record is traced back to the Albian. These units contain few planktonic and benthic fossils. Unit V at Site 959 is composed of quartz sandstone and silty claystone, and Unit V at Site 960 is divided into Subunits 
VA (micritic or sideritic silty stone) and VB (silty stone). Structural inversion is indicated by the transformation of the depositional basin into the uplifted block, which currently defines the Marginal Ridge and southern border of the Deep Ivorian Basin (Fig. 1). The construction of the Marginal Ridge could be caused by the decoupling of the South American and African continents (Mascle and Blarez, 1987). Structural geology studies show that major tectonic deformation of both the compressional and extensional type developed during this stage. Hence, the dip of bedding displays a wide spectrum of values with more than a $60^{\circ}$ angle (Mascle, Lohmann, Clift, et al., 1996). Index properties indicate $<30 \%$ porosity of sediments (Mascle, Lohmann, Clift, et al., 1996). The maximum uplift of the Marginal Ridges and the subsequent cessation of active transform tectonism correspond to the end of the Syntransform Basin Stage. An unconformity records the change of the stage at both sites. The uplift and associated deformation probably terminated the sedimentation during the latest Albian to early Turonian (Mascle, Lohmann, Clift, et al., 1996).

The sediments overlying the unconformity are pelagic and periplatform carbonate deposits, dated as middle Turonian and early Turonian at Sites 959 and 960, respectively. The carbonates symbolizing the Marginal Ridge Emergence Stage are recorded in lithologic Unit IV at both sites. Unit IV at Site 959 is divided into Subunits IVA (sandy limestone) and IVB (limestone), and is dated as Turonian through Coniacian. Unit IV at Site 960 is composed of Subunit IVA (containing phosphate and glauconite) and IVB (carbonate-rich). These units are dated as Turonian through Maastrichtian.

The limestone sequences at both Sites 959 and 960 have been overlain by pelagic deposits of the Passive Margin Stage. This follows the demise of shallow-water carbonate sedimentation at the end of the Marginal Ridge Emergence Stage and is characterized by a lack of coarse-grained clastic input into the Deep Ivorian Basin. This stage starts lithologic Unit III at both sites. Lithology of the pelagic deposits changes from condensed claystone of Late Cretaceous age to nannofossil and foraminifer ooze of Pleistocene age. Unit III at Site 959 is early Coniacian to late Paleocene in age and consists of claystone with nannofossils. Unit II at Site 959 is late Paleocene to early Miocene in age, and contains biosiliceous sediments. This unit is divided into Subunits IIA (diatomite with chalk), IIB (chert and claystone), and IIC (porcellanite). The chert in Subunit IIB is dated as early Oligocene. Lithologic Unit III at Site 960 is palygorskite claystone from the early Eocene. Unit II at Site 960 also contains biosiliceous sediments and is divided into Subunits IIA (containing radiolarian chalk) and IIB (chert and porcellanite). This unit records the early Eocene to early Miocene. Lithologic Unit I at both Sites 959 and 960 has nannofossil and foraminifer ooze after the early Miocene. Lithologic Unit I at both sites is divided into Subunits IA (more pyrite) and IB (partly glauconitic).

\section{METHODS Magnetic Fabric Analysis}

AMS is determined by comparing magnetic susceptibility values in three orthogonal axes. These three principal magnetic susceptibility axes are represented by the symbols $K_{\max }, K_{\text {int }}$, and $K_{\min }$. The magnetic susceptibility values of the three axes define an ellipsoid of magnetic susceptibility. The evolution of an ellipsoid of magnetic susceptibility can reflect finite strain at the deformation stage.

In this paper, the following parameters were used to describe the shape and the degree of magnetic anisotropy:

$$
\begin{gathered}
L=K_{\text {max }} / K_{\text {int }}, \\
F=K_{\text {max }} / K_{\text {min }}, \\
P^{\prime}=\exp \left(\operatorname{sqrt}\left\{2 \cdot\left[(N 1-N)^{2}+(N 2-N)^{2}+(N 3-N)^{2}\right]\right\}\right),
\end{gathered}
$$

$$
T=\left(2 \cdot K_{\text {int }}-K_{\max }-K_{\min }\right) /\left(K_{\max }-K_{\min }\right),
$$

where $K_{\max }$ is the maximum, $K_{\text {int }}$ the intermediate, and $K_{\min }$ the minimum intensity axis of the susceptibility ellipsoid, respectively. $N 1=$ $\ln K_{\max } ; N 2=\ln K_{\text {int }} ; N 3=\ln K_{\min } ;$ and $N=\left(K_{\max }+K_{\text {int }}+K_{\text {min }}\right) / 3$.

The eccentricity of a magnetic susceptibility ellipsoid can be expressed by the ratios of the axial values. $L$ value is a parameter that indicates the lineation of the magnetic fabric (Balsley and Buddington, 1960). $F$ value is the foliation of the fabric (Stacey et al., 1960). The degree of magnetic anisotropy is indicated by $P^{\prime}$ value (Jelinek, 1981). $T$ value ranges from -1 to +1 , and is available to serve as a shape factor in combination with $P^{\prime}$ value, (i.e., if $T<0[T>0]$, the view of the magnetic fabric is linear [foliated], and the susceptibility ellipsoid is prolate [oblate]; Jelinek, 1981).

The primary grains deposited on the ground may form a horizontal oblate ellipsoid of magnetic susceptibility, although an imbrication effect can be expected if there is a current (Rees and Woodall, 1975; Taira, 1989). After deposition, the magnetic fabric may be affected by compaction so that the ellipsoid of magnetic susceptibility develops into a more oblate shape, while the degree of anisotropy increases. Further deformation will affect the magnetic fabric. A horizontal compressional stress may result in a prolate ellipsoid (or pencil structure) because the radius in the direction of the strain axis can be shortened further. A continued strain flattens the ellipsoid of magnetic susceptibility horizontally and is expected to produce an oblate ellipsoid again that dips steeply.

In this study, we determined the magnetic fabrics of lithologic Units III, IV, and V at Hole 959D; Units I, II, IV, and V at Hole 960A; and Unit III at Hole 962D. To minimize the effect of lithologic variation, only fine-grained sedimentary rocks were selected. $10-\mathrm{cm}^{3}$ samples were taken and sealed in plastic cases on board. Four additional cubes were taken from whole-round cores after X-ray CT scanning, avoiding mineral-filled veins or pyrite grains. The AMS was obtained by 15 direction measurements for each specimen using a magnetic susceptibility meter, Geofyzika Brno Kappabridge KLY-2, at the Ocean Research Institute, University of Tokyo. This instrument gives a sensitivity for a specimen of nominal volume $10-\mathrm{cm}^{3}$ of $4 \times$ $10^{-8} \mathrm{SI}$ units, with a relative accuracy of $0.1 \%$ and an absolute calibration accuracy of $3 \%$.

The declinations and the inclinations of magnetic susceptibility ellipsoid calculated relative to the core liner are shown in Table 1. However, the AMS directions are not corrected to the original orientation because the intensity of remanent magnetization for each specimen is too low for the core orientations to be determined.

\section{X-ray Computed Tomography Scan Analysis}

The CT-scan system used in this study is a Toshiba X-force TCT$700 \mathrm{~S}$ at the Technology Research Center, Japan National Oil Corporation (JNOC). The X-ray source of this system produces a fanshaped, collimated, irradiating beam. The peak of radiation used in this study is $130 \mathrm{kV}$. The slice width is $2 \mathrm{~mm}$ and the inspection time is $2 \mathrm{~min} / \mathrm{slice}$. The relationship between the intensity of the incident beam $I_{o}$ and transmitted beam $I$ is defined as follows:

$$
I=I_{o} \exp \left(-\sum \mu D\right)
$$

where $D$ is the sample thickness and $\mu$ is the linear attenuation coefficient. The CT value used in this paper is the ratio of the linear attenuation coefficient $\mu$ of the material to that of pure water.

CT-scan analysis was performed on four whole-round cores from Hole 959D, Samples 159-959D-54R-1, 89-99 cm, 65R-2, 117-126 $\mathrm{cm}, 72 \mathrm{R}-3,72-82 \mathrm{~cm}$, and 78R-3, 50-60 cm, and on two from Hole 962D, Samples 159-962D-9R-4, 45-55 cm, and 34R-1, 61-71 cm. The CT values for cubic specimens (Table 1 ) are averaged CT values for slices of 2-mm finite thickness. The CT value of Sample 159- 
959D-72R-3, 72-82 cm, was obtained from the point of an internally undisturbed pebble that was preserved in drilling disturbed sediments.

\section{RESULTS AMS Analysis}

The results of AMS and CT scan analyses are shown in Table 1. The shapes of determined ellipsoids of magnetic susceptibility show a horseshoe-shaped variation symmetrically with $T=0$ (Fig. 2A). Specimens measured from lithologic Unit III of Hole 959D between Section 159-959D-53R-6 and 66R-2 are all claystone. The magnetic anisotropy parameters range from 1.0 to 1.04 in $P^{\prime}$ value and between -0.7 and 1.0 in $T$ value. $N$ value, the mean of magnetic susceptibility, of Unit III ranges generally from $20 \times 10^{-6}$ to $50 \times 10^{-6}$ SI. No samples were analyzed from Subunit IVB because the composition is limestone, which represents the Marginal Ridge Emergence Stage extending between 1062.7 and 1081.7 mbsf. However, a specimen from Section 159-959D-67R-2 (1045 mbsf) was measured from lithologic Subunit IVA. It is sandy dolomite overlying the limestone of Subunit IVB. The $N$ value of a specimen is $54 \times 10^{-6} \mathrm{SI}$, its $P^{\prime}$ value is 1.015 , and its $T$ value is 0.735 . The plot is included in the variational extent of the claystone from Unit III. The specimens from Unit $\mathrm{V}$, which are fine sandstone, have consistently negative $T$ values from -0.91 to -0.22 , and Sample 159-959A-77R-2, 67-69 cm (1141 mbsf), has the highest degree of magnetic anisotropy, 1.131 in $P^{\prime}$ value, and a $T$ value of -0.907 . Its lineation parameter $L$ shows a remarkably high value of 1.110 (Fig. 2B). The AMS of three fine sandstone pebbles, which were preserved in drilling-disturbed whole-round Sample 159-959A-72R-3, 72-82 cm (1094 mbsf), were also measured and plotted for reference as $959-\mathrm{V}^{\prime}$ (Fig. 2). Their orientations in relation to the core liner could not be recorded because of the severe disturbance. $N$ values of Unit V indicate $>130 \times 10^{-6}$ SI, except from specimens from the drilling-disturbed core.

The specimens from lithologic Subunit IB at Hole 960A are claystone and have a low anisotropy degree of $<1.01 P^{\prime}$ value and a narrow range of $T$ value, -0.3 to 0.1 , which indicate an almost spheric ellipsoid of magnetic susceptibility $\left(K_{\max }=K_{\text {int }}=K_{\min }\right)$. Subunit IIA is composed of claystone or silty sandstone, which has a wide range of $T$ values, from -0.440 to 0.682 , but the magnetic anisotropy is very low, $<1.004$ in $P^{\prime}$ value. The samples between lithologic Subunits IB and IIA are pelagic soft sediments, and show little lineation and foliation (Fig. 2B). $N$ values from these specimens range generally from $40 \times 10^{-6}$ to $70 \times 10^{-6}$ SI, except for Sample $159-960$ D-12R-3, 55-57 $\mathrm{cm}(101 \mathrm{mbsf})$, a sandstone of $365 \times 10^{-6} \mathrm{SI}$. Six specimens of quartzsand-bearing limestone between Sections 159-960A-25R-2 and 36R1 were analyzed from Subunit IVB; however, because the magnetic susceptibility is below the susceptibility of the equipment, these samples were not used in this study.

Samples from lithologic Unit V at Hole 960A show a large variation of magnetic susceptibility anisotropy. Subunit VA is composed of a bimodal variation of magnetic fabric in which one is the negative $T$ value group and the other is the positive $T$ value group. Eight specimens located between Samples 159-960A-44R-2, 80-82 cm (364 mbsf), and 47R-1, 99-101 cm (377 mbsf), which consist of claystone to silty sandstone, have negative $T$ values and $P^{\prime}$ values ranging from 1.02 to 1.12 . High $L$ values and low $F$ values (Fig. $2 \mathrm{~B}$ ) indicate prolate ellipsoids of magnetic susceptibility. The other specimens from Subunit VA, both from 159-960A-40R-1, 20-22 cm, to 43R-1, 34$36 \mathrm{~cm}$, and 49R-1, 102-104 cm, to 53R-1, 10-12 cm, are within the positive $T$ group. All these samples are claystone. They do not overlap in either $T$ or $P^{\prime}$ values, and concentrate from 0.89 to 0.98 in $T$ value and from 1.15 to 1.20 in $P^{\prime}$ value. They have low lineation and high foliation, and contrast well with the above negative $T$ value group (Fig. 2B). $N$ values of Subunit VA have a wide range from 140 $\times 10^{-6}$ to $580 \times 10^{-6} \mathrm{SI}$. Lithologic Subunit VB is composed of claystone to silty sandstone, with a degree of anisotropy $P^{\prime}$ ranging from 1.00 to 1.25 . For $P^{\prime}$ values $>1.05$, the $T$ values are consistently confined between 0.8 and 1.0, which indicates oblate ellipsoids of magnetic susceptibility. They show lower $L$ values than 1.016 but high $F$ values of up to 1.204 (Fig. 2B). Furthermore, $N$ values from Subunit VB have a wide range from $150 \times 10^{-6}$ to $920 \times 10^{-6} \mathrm{SI}$.

Two specimens from lithologic Unit III of Hole 962D were taken from the whole-round cores after CT scanning. The magnetic fabric analyses show low degrees of anisotropy (i.e., $P^{\prime}<1.02$, so that the shape of the magnetic susceptibility ellipsoid is nearly spherical $\left[K_{\max }\right.$ $\left.=K_{\text {int }}=K_{\text {min }}\right]$ ).

\section{CT Scan Analysis}

CT values obtained from three specimens at Hole 959D systematically increase downward and correlate with the changes in bulk density and in porosity from index properties measurements (Mascle, Lohmann, Clift, et al., 1996). CT values of two cubes taken from lithologic Unit III of Hole 959D, Samples 159-959D-54R-1, 94-96 $\mathrm{cm}$, and 65R-2, 122-124 cm (919 mbsf and $1026 \mathrm{mbsf}$, respectively), indicate 1369 and 1648. These specimens are claystone. A piece of fine quartz sandstone pebble from drilling-disturbed Sample 159959D-72R-3, 72-82 cm (1094 mbsf), in Unit V has a high CT value of 2530 . This indicates a higher density than the above two specimens in Unit III. However, there is little change in grain density at $2.7 \mathrm{~g} /$ $\mathrm{cm}^{3}$ from Unit III to Unit V of Hole 959D (Mascle, Lohmann, Clift, et al., 1996). Although the drilling disturbance might have somewhat reflected, the pebble specimen from the drilling-disturbed sample could be used in this study because of the difference between the dehydration degree resulting from compaction and deformation.

CT values of the two cubes taken from whole-round cores (157 and 369 mbsf) at Hole 962D result in 1536 and 1835.

\section{DISCUSSION}

The AMS analysis provides three types of fabric, Types 1, 2, and 3 , in the shape of the magnetic susceptibility ellipsoid.

Type 1 is the low-degree magnetic anisotropy type, which is typical of lithologic Unit III and Subunit IVA at Hole 959D, Subunits IB and IIA at Hole 960A, and Unit III at Hole 962D. This type of sediment retains original sedimentary fabric, and Flinn-type plots further show a finite variation concentrated in very low lineation and foliation (Fig. 2B). The porosity of Subunits IB and IIA from the Cenozoic at Hole $960 \mathrm{~A}$ is high, ranging from $60 \%$ to $75 \%$. This is also supported by a lower density value obtained by CT scan analysis. Lithologic Unit III at Hole 960A, which is from the Late Cretaceous, has $35 \%$ to $50 \%$ porosity. This suggests that sediments have not undergone effectively constrained compaction. The difference in the degree of AMS between this type and the other high-degree magnetic anisotropy types seen below may reflect the contrast between the overlying post-transform deposits and the underlying syntransform deposits.

Type 2 is the positive $T$ value-high-anisotropy-degree type, which is typical of lithologic Unit V at Hole 960A, except for the interval between 360 and 380 mbsf. The sediments in this type are claystone to silty sandstone and have less than $25 \%$ porosity. When comparing grain-size groups, the finer sediments seem to have the higher degree of magnetic anisotropy. Most of the claystone has a high $P^{\prime}$ value, greater than 1.15 , whereas the silty sandstone is lower than 1.15. This type of magnetic fabric was reported (e.g., Sagnotti et al., 1994) from the extensional Tyrrhenian margin in central Italy and (Kanamatsu, 1996) from the Boso-Miura collision zone in central Japan. We interpret this type of fabric to represent a deformed sedimentary fabric. 
Table 1. AMS parameters and orientations of ellipsoids of MS and CT values.

\begin{tabular}{|c|c|c|c|c|c|c|c|c|c|c|c|c|c|c|c|}
\hline $\begin{array}{l}\text { Core, section, interval } \\
(\mathrm{cm})\end{array}$ & $\begin{array}{l}\text { Lith. } \\
\text { unit }\end{array}$ & $\begin{array}{l}\text { Depth } \\
\text { (mbsf) }\end{array}$ & Lithology & $\stackrel{\mathrm{N}}{\mathrm{SI}\left(\times 10^{-6}\right)}$ & $L$ & $F$ & $P^{\prime}$ & $T$ & $K_{\max } D$ & $K_{\max } I$ & $\begin{array}{c}K_{\text {int }} D \\
\left({ }^{\circ}\right)\end{array}$ & $\begin{array}{c}K_{\text {int }} I \\
\left({ }^{\circ}\right)\end{array}$ & $\underset{\left({ }^{\circ}\right)}{K_{\min } D}$ & $\underset{\left(^{\circ}\right)}{K_{\min } I}$ & CT value \\
\hline 159-959D- & & & & & & & & & & & & & & & \\
\hline 53R-6, 21-23 & III & 914.99 & Claystone & 154.80 & 1.001 & 1.001 & 1.002 & 0.177 & 239 & 42 & 333 & 3 & 66 & 47 & \\
\hline $54 \mathrm{R}-1,94-96$ & & 919.04 & Claystone & 563.80 & 1.004 & 1.012 & 1.016 & 0.517 & 26 & 1 & 116 & 22 & 292 & 68 & 1369 \\
\hline $55 \mathrm{R}-4,57-59$ & & 931.63 & Claystone & 35.79 & 1.008 & 1.008 & 1.016 & 0.043 & 64 & 21 & 301 & 56 & 165 & 26 & \\
\hline $56 \mathrm{R}-3,111-113$ & & 941.53 & Claystone & 49.15 & 1.010 & 1.007 & 1.017 & -0.154 & 253 & 7 & 347 & 32 & 153 & 57 & \\
\hline $56 \mathrm{R}-6,95-97$ & & 945.85 & Claystone & 45.03 & 1.007 & 1.003 & 1.010 & -0.367 & 214 & 17 & 310 & 18 & 84 & 65 & \\
\hline $57 \mathrm{R}-1,57-59$ & & 947.67 & Claystone & 38.83 & 1.000 & 1.016 & 1.019 & 0.973 & 176 & 17 & 81 & 16 & 310 & 66 & \\
\hline $57 \mathrm{R}-1,78-80$ & & 947.88 & Claystone & 46.51 & 1.008 & 1.007 & 1.015 & -0.086 & 109 & 49 & 243 & 32 & 349 & 24 & \\
\hline $58 \mathrm{R}-3,86-88$ & & 959.97 & Claystone & 36.15 & 1.008 & 1.009 & 1.017 & 0.033 & 80 & 6 & 347 & 33 & 179 & 56 & \\
\hline $58 \mathrm{R}-4,51-53$ & & 961.12 & Claystone & 39.87 & 1.003 & 1.002 & 1.004 & -0.288 & 255 & 11 & 162 & 18 & 15 & 69 & \\
\hline $59 \mathrm{R}-3,148-150$ & & 970.98 & Claystone & 28.19 & 1.007 & 1.010 & 1.017 & 0.161 & 125 & 31 & 245 & 40 & 10 & 34 & \\
\hline $59 \mathrm{R}-4,54-56$ & & 971.54 & Claystone & 31.63 & 1.002 & 1.006 & 1.008 & 0.509 & 9 & 23 & 135 & 55 & 267 & 25 & \\
\hline $60 \mathrm{R}-3,40-42$ & & 979.50 & Claystone & 29.48 & 1.009 & 1.007 & 1.016 & -0.174 & 47 & 61 & 289 & 15 & 192 & 24 & \\
\hline $60 \mathrm{R}-5,27-29$ & & 982.37 & Claystone & 41.68 & 1.006 & 1.002 & 1.009 & -0.461 & 210 & 51 & 82 & 27 & 337 & 26 & \\
\hline 61R-3, 66-68 & & 989.46 & Claystone & 25.30 & 1.012 & 1.024 & 1.036 & 0.334 & 165 & 23 & 261 & 14 & 19 & 63 & \\
\hline $62 \mathrm{R}-2,145-147$ & & 998.35 & Claystone & 10.99 & 1.016 & 1.017 & 1.034 & 0.027 & 101 & 25 & 208 & 31 & 340 & 48 & \\
\hline $62 \mathrm{R}-3,60-62$ & & 999.00 & Claystone & 20.56 & 1.006 & 1.012 & 1.019 & 0.314 & 341 & 23 & 92 & 39 & 228 & 42 & \\
\hline $63 \mathrm{R}-2,140-142$ & & 1007.90 & Claystone & 19.73 & 1.012 & 1.002 & 1.016 & -0.683 & 22 & 63 & 139 & 13 & 235 & 23 & \\
\hline $63 \mathrm{R}-4,29-31$ & & 1009.79 & Claystone & 22.16 & 1.014 & 1.009 & 1.023 & -0.225 & 278 & 69 & 87 & 21 & 178 & 4 & \\
\hline $64 \mathrm{R}-1,142-144$ & & 1016.12 & Claystone & 33.15 & 1.007 & 1.013 & 1.021 & 0.260 & 269 & 11 & 8 & 39 & 166 & 48 & \\
\hline $64 \mathrm{R}-4,7-9$ & & 1019.27 & Claystone & 49.27 & 1.007 & 1.009 & 1.016 & 0.160 & 25 & 12 & 292 & 9 & 166 & 74 & \\
\hline $65 \mathrm{R}-1,92-94$ & & 1025.02 & Claystone & 41.75 & 1.002 & 1.007 & 1.009 & 0.487 & 119 & 32 & 311 & 57 & 212 & 5 & \\
\hline $65 \mathrm{R}-2,122-124$ & & 1026.82 & Claystone & 331.50 & 1.001 & 1.008 & 1.010 & 0.808 & 337 & 6 & 68 & 11 & 216 & 78 & 1648 \\
\hline $65 \mathrm{R}-5,113-115$ & & 1031.23 & Claystone & 47.65 & 1.002 & 1.020 & 1.024 & 0.772 & 315 & 8 & 225 & 0 & 135 & 82 & \\
\hline $66 \mathrm{R}-1,105-107$ & & 1034.75 & Claystone & 27.69 & 1.006 & 1.025 & 1.033 & 0.615 & 224 & 14 & 129 & 19 & 348 & 66 & \\
\hline $66 \mathrm{R}-2,16-18$ & & 1035.36 & Claystone & 57.05 & 1.003 & 1.012 & 1.016 & 0.557 & 336 & 10 & 69 & 15 & 214 & 71 & \\
\hline 67R-2, 114-116 & & 1045.94 & Sandy dolomite & 54.09 & 1.002 & 1.012 & 1.015 & 0.735 & 3 & 66 & 196 & 23 & 104 & 5 & \\
\hline 71R-1, 92-94 & & 1082.62 & Fine sandstone & 149.70 & 1.006 & 1.004 & 1.010 & -0.222 & 201 & 34 & 328 & 42 & 89 & 30 & \\
\hline $72 \mathrm{R}-3,72-82(1)$ & & 1094.92 & Fine sandstone & 95.85 & 1.211 & 1.055 & 1.294 & -0.562 & & & & & & & 2530 \\
\hline $72 \mathrm{R}-3,72-82(2)$ & & 1094.92 & Fine sandstone & 57.76 & 1.118 & 1.016 & 1.148 & -0.751 & & & & & & & \\
\hline $72 \mathrm{R}-3,72-82(3)$ & & 1094.92 & Fine sandstone & 99.36 & 1.038 & 1.022 & 1.061 & -0.261 & & & & & & & \\
\hline $74 \mathrm{R}-1,51-53$ & & 1111.01 & Fine sandstone & 130.00 & 1.032 & 1.005 & 1.040 & -0.708 & 79 & 3 & 183 & 77 & 348 & 13 & \\
\hline $76 \mathrm{R}-1,69-71$ & & 1130.49 & Fine sandstone & 153.40 & 1.006 & 1.003 & 1.010 & -0.280 & 188 & 56 & 300 & 15 & 39 & 30 & \\
\hline 77R-2, 67-69 & & 1141.67 & Silty sandstone & 347.30 & 1.110 & 1.005 & 1.131 & -0.907 & 298 & 74 & 194 & 4 & 103 & 16 & \\
\hline 159-960A- & & & & & & & & & & & & & & & \\
\hline 10R-1, 60-62 & ID & 78.90 & Claystone & 57.39 & 1.001 & 1.002 & 1.003 & 0.068 & 114 & 17 & 212 & 25 & 354 & 59 & \\
\hline 10R-4, 35-37 & & 83.15 & Claystone & 41.03 & 1.001 & 1.002 & 1.003 & 0.091 & 305 & 23 & 158 & 63 & 41 & 13 & \\
\hline $10 \mathrm{R}-5,90-92$ & & 85.20 & Claystone & 38.73 & 1.002 & 1.002 & 1.004 & 0.046 & 90 & 0 & 360 & 68 & 180 & 22 & \\
\hline 11R-1, 99-101 & & 88.99 & Siltstone & 60.52 & 1.004 & 1.003 & 1.007 & -0.122 & 268 & 52 & 43 & 29 & 146 & 23 & \\
\hline $12 \mathrm{R}-1,90-92$ & & 98.50 & Claystone & 72.77 & 1.003 & 1.001 & 1.004 & -0.271 & 294 & 48 & 35 & 9 & 133 & 40 & \\
\hline $12 \mathrm{R}-3,55-57$ & 171 & 101.15 & Silty sandstone & 365.70 & 1.000 & 1.001 & 1.002 & 0.682 & 135 & 0 & 225 & 9 & 45 & 81 & \\
\hline $13 \mathrm{R}-1,37-39$ & & 107.67 & Claystone & 53.61 & 1.001 & 1.002 & 1.003 & 0.378 & 303 & 17 & 45 & 35 & 192 & 50 & \\
\hline $15 \mathrm{R}-1,41-43$ & & 127.01 & Claystone & 47.62 & 1.003 & 1.001 & 1.004 & -0.440 & 290 & 3 & 21 & 28 & 195 & 62 & \\
\hline $40 \mathrm{R}-1,20-22$ & VA & 348.50 & Claystone & 393.50 & 1.001 & 1.146 & 1.171 & 0.986 & 189 & 25 & 83 & 31 & 310 & 48 & \\
\hline $43 \mathrm{R}-1,34-36$ & & 357.84 & Claystone & 311.50 & $\begin{array}{l}1.001 \\
1.001\end{array}$ & $\begin{array}{l}1.140 \\
1.166\end{array}$ & 1.196 & 0.968 & 128 & 4 & 218 & 1 & 328 & $\begin{array}{l}40 \\
86\end{array}$ & \\
\hline $44 \mathrm{R}-2,80-82$ & & 364.60 & Siltstone & 338.80 & 1.032 & 1.008 & 1.043 & -0.596 & 169 & 86 & 24 & 3 & 294 & 2 & \\
\hline $44 R-3,4-6$ & & 365.34 & Siltstone & 578.20 & 1.033 & 1.002 & 1.039 & -0.873 & 310 & 76 & 133 & 14 & 43 & 1 & \\
\hline $45 \mathrm{R}-1,44-46$ & & 367.64 & Claystone & 379.80 & 1.098 & 1.007 & 1.119 & -0.859 & 131 & 79 & 276 & 9 & 7 & 6 & \\
\hline $45 \mathrm{R}-2,104-106$ & & 368.89 & Siltstone & 419.90 & 1.056 & 1.003 & 1.067 & -0.893 & 53 & 66 & 224 & 24 & 315 & 4 & \\
\hline $46 \mathrm{R}-2,19-21$ & & 373.49 & Silty sandstone & 141.30 & 1.019 & 1.005 & 1.025 & -0.579 & 257 & 75 & 94 & 14 & 3 & 4 & \\
\hline $46 \mathrm{R}-2,52-54$ & & 373.82 & Silty sandstone & 191.00 & 1.012 & 1.006 & 1.019 & -0.311 & 256 & 73 & 110 & 14 & 18 & 9 & \\
\hline $47 \mathrm{R}-1,65-67$ & & 377.45 & Claystone & 260.10 & 1.069 & 1.004 & 1.082 & -0.899 & 289 & 45 & 80 & 41 & 183 & 15 & \\
\hline $47 \mathrm{R}-1,99-101$ & & 377.79 & Claystone & 247.50 & 1.079 & 1.003 & 1.093 & -0.933 & 272 & 44 & 82 & 46 & 177 & 5 & \\
\hline $49 \mathrm{R}-1,102-104$ & & 387.42 & Claystone & 544.40 & 1.001 & 1.127 & 1.149 & 0.975 & 258 & 32 & 150 & 28 & 27 & 46 & \\
\hline 49R-cc, 6-8 & & 388.30 & Claystone & 525.60 & 1.006 & 1.161 & 1.192 & 0.917 & 283 & 29 & 180 & 23 & 58 & 52 & \\
\hline $52 \mathrm{R}-1,145-147$ & & 398.75 & Claystone & 418.90 & 1.008 & 1.146 & 1.176 & 0.893 & 296 & 8 & 204 & 11 & 62 & 76 & \\
\hline $53 \mathrm{R} 1,10-12$ & & 403.40 & Claystone & 469.30 & 1.002 & 1.161 & 1.190 & 0.975 & 288 & 3 & 18 & 2 & 148 & 86 & \\
\hline $54 \mathrm{R}-1,27-29$ & & 413.37 & Silty claystone & 422.70 & 1.016 & 1.170 & 1.210 & 0.818 & 270 & 30 & 164 & 25 & 42 & 49 & \\
\hline $54 \mathrm{R}-1,135-137$ & & 414.45 & Silty claystone & 432.70 & 1.001 & 1.053 & 1.062 & 0.962 & 167 & 21 & 63 & 31 & 286 & 51 & \\
\hline 54R-3, 47-49 & & 416.57 & Silty claystone & 734.90 & 1.009 & 1.123 & 1.150 & 0.852 & 269 & 7 & 176 & 20 & 17 & 69 & \\
\hline $56 \mathrm{R}-1,96-98$ & & 423.76 & Claystone & 461.30 & 1.001 & 1.088 & 1.103 & 0.981 & 331 & 9 & 61 & 4 & 178 & 80 & \\
\hline 56R-1, 116-118 & & 423.96 & Claystone & 602.30 & 1.002 & 1.060 & 1.071 & 0.926 & 255 & 8 & 165 & 4 & 47 & 81 & \\
\hline $57 \mathrm{R}-1,33-35$ & & 427.73 & Sandy siltstone & 309.80 & 1.010 & 1.087 & 1.107 & 0.790 & 223 & 3 & 313 & 8 & 113 & 81 & \\
\hline $57 \mathrm{R}-1,119-121$ & & 428.59 & Sandy siltstone & 466.60 & 1.002 & 1.043 & 1.051 & 0.914 & 190 & 6 & 99 & 7 & 320 & 81 & \\
\hline 57R-2, 79-81 & & 429.69 & Sandy siltstone & 924.70 & 1.002 & 1.115 & 1.135 & 0.961 & 172 & 14 & 81 & 5 & 330 & 75 & \\
\hline 58R-1, 77-79 & & 433.17 & Silty claystone & 263.80 & 1.008 & 1.203 & 1.244 & 0.916 & 59 & 2 & 329 & 8 & 160 & 82 & \\
\hline $58 \mathrm{R}-2,118-120$ & & 435.01 & Silty claystone & 286.60 & 1.004 & 1.203 & 1.242 & 0.954 & 72 & 1 & 342 & 6 & 173 & 84 & \\
\hline $58 \mathrm{R}-2,122-124$ & & 435.04 & Silty claystone & 156.00 & 1.006 & 1.204 & 1.243 & 0.941 & 283 & 4 & 15 & 26 & 184 & 63 & \\
\hline $58 \mathrm{R}-3,1-3$ & & 435.18 & Silty claystone & 364.00 & 1.005 & 1.199 & 1.237 & 0.943 & 246 & 1 & 336 & 3 & 144 & 87 & \\
\hline 58R-cc, $11-13$ & & 436.13 & Silty claystone & 327.20 & 1.006 & 1.190 & 1.226 & 0.938 & 293 & 9 & 203 & 1 & 108 & 81 & \\
\hline $59 \mathrm{R}-1,26-28$ & & 437.26 & Silty claystone & 270.40 & 1.004 & 1.162 & 1.193 & 0.943 & 279 & 2 & 9 & 3 & 158 & 86 & \\
\hline $59 \mathrm{R}-1,99-101$ & & 437.99 & Silty sandstone & 256.20 & 1.009 & 1.035 & 1.047 & 0.590 & 263 & 15 & 170 & 11 & 46 & 71 & \\
\hline 59R-2, 8-10 & & 438.35 & Silty sandstone & 296.30 & 1.006 & 1.126 & 1.151 & 0.906 & 348 & 4 & 258 & 2 & 134 & 86 & \\
\hline $59 \mathrm{R}-2,83-85$ & & 439.10 & Silty sandstone & 507.00 & 1.003 & 1.017 & 1.022 & 0.734 & 104 & 7 & 13 & 10 & 229 & 78 & \\
\hline $59 \mathrm{R}-3,41-43$ & & 440.17 & Silty sandstone & 413.30 & 1.003 & 1.001 & 1.004 & -0.595 & 248 & 17 & 152 & 18 & 19 & 64 & \\
\hline $60 \mathrm{R}-1,65-67$ & & 442.65 & Silty sandstone & 293.70 & 1.004 & 1.014 & 1.020 & 0.530 & 148 & 25 & 245 & 15 & 4 & 61 & \\
\hline $60 \mathrm{R}-2,52-54$ & & 443.85 & Silty sandstone & 370.20 & 1.005 & 1.070 & 1.085 & 0.858 & 168 & 1 & 78 & 18 & 260 & 72 & \\
\hline 60R-2, 67-69 & & 444.00 & Silty sandstone & 391.90 & 1.005 & 1.100 & 1.120 & 0.894 & 59 & 7 & 328 & 10 & 182 & 78 & \\
\hline $61 \mathrm{R}-1,106-108$ & & 447.26 & Silty sandstone & 473.10 & 1.006 & 1.048 & 1.060 & 0.772 & 187 & 24 & 94 & 8 & 347 & 64 & \\
\hline $61 \mathrm{R}-1,126-128$ & & 447.46 & Silty sandstone & 191.90 & 1.002 & 1.133 & 1.157 & 0.969 & 71 & 24 & 338 & 8 & 230 & 64 & \\
\hline $61 \mathrm{R}-2,29-31$ & & 447.97 & Silty sandstone & 405.10 & 1.009 & 1.023 & 1.032 & 0.448 & 185 & 10 & 280 & 26 & 74 & 62 & \\
\hline
\end{tabular}


Table 1 (continued).

\begin{tabular}{|c|c|c|c|c|c|c|c|c|c|c|c|c|c|c|c|}
\hline $\begin{array}{l}\text { Core, section, interval } \\
(\mathrm{cm})\end{array}$ & $\begin{array}{l}\text { Lith. } \\
\text { unit }\end{array}$ & $\begin{array}{l}\text { Depth } \\
\text { (mbsf) }\end{array}$ & Lithology & $\begin{array}{c}\mathrm{N} \\
\operatorname{SI}\left(\times 10^{-6}\right)\end{array}$ & $L$ & $F$ & $P^{\prime}$ & $T$ & $K_{\max }{ }^{\circ} D$ & $K_{\max } I$ & $\begin{array}{c}K_{\text {int }} D \\
\left.{ }^{\circ}\right)\end{array}$ & $\begin{array}{c}K_{\text {int }} I \\
\left(^{\circ}\right)\end{array}$ & $\underset{\left({ }^{\circ}\right)}{K_{\min } D}$ & $\underset{\left({ }^{\circ}\right)}{K_{\min } I}$ & $\mathrm{CT}$ value \\
\hline \multicolumn{16}{|l|}{ 159-962D- } \\
\hline $\begin{array}{l}\text { 9R-4, 49-51 } \\
34 \mathrm{R}-1,64-66\end{array}$ & 110 & $\begin{array}{l}157.55 \\
369.94\end{array}$ & $\begin{array}{l}\text { Fine sandstone } \\
\text { Siltstone }\end{array}$ & $\begin{array}{l}254.80 \\
923.20\end{array}$ & $\begin{array}{l}1.003 \\
1.001\end{array}$ & $\begin{array}{l}1.011 \\
1.002\end{array}$ & $\begin{array}{l}1.015 \\
1.003\end{array}$ & $\begin{array}{l}0.519 \\
0.188\end{array}$ & $\begin{array}{l}118 \\
272\end{array}$ & $\begin{array}{l}31 \\
21\end{array}$ & $\begin{array}{l}27 \\
39\end{array}$ & $\begin{array}{r}2 \\
57\end{array}$ & $\begin{array}{l}293 \\
172\end{array}$ & $\begin{array}{l}59 \\
24\end{array}$ & $\begin{array}{l}1536 \\
1835\end{array}$ \\
\hline
\end{tabular}

Notes: The declinations and the inclinations of the MS ellipsoids were computed from the relation to the core liner. $\mathrm{N}=$ mean of magnetic susceptibility, $\mathrm{L}=$ magnetic lineation, $\mathrm{F}=$ magnetic foliation, $\mathrm{P}^{\prime}=$ degree of magnetic anisotropy, $\mathrm{T}=$ shape of magnetic anisotropy. $K_{\max }, K_{\text {int }}$, and $K_{\min }$ are the maximum, the intermediate, and the minimum intensity axes of the susceptibility ellipsoid, respectively. D and I are the declination and the inclination, respectively, of each axis of the susceptibility ellipsoids. Samples $159-959 \mathrm{D}-72 \mathrm{R}-3$, $72-82 \mathrm{~cm}(1),(2)$, and (3) are internally undisturbed fine sandstone pebbles that have been preserved in drilling-disturbed sediments.

\section{A}

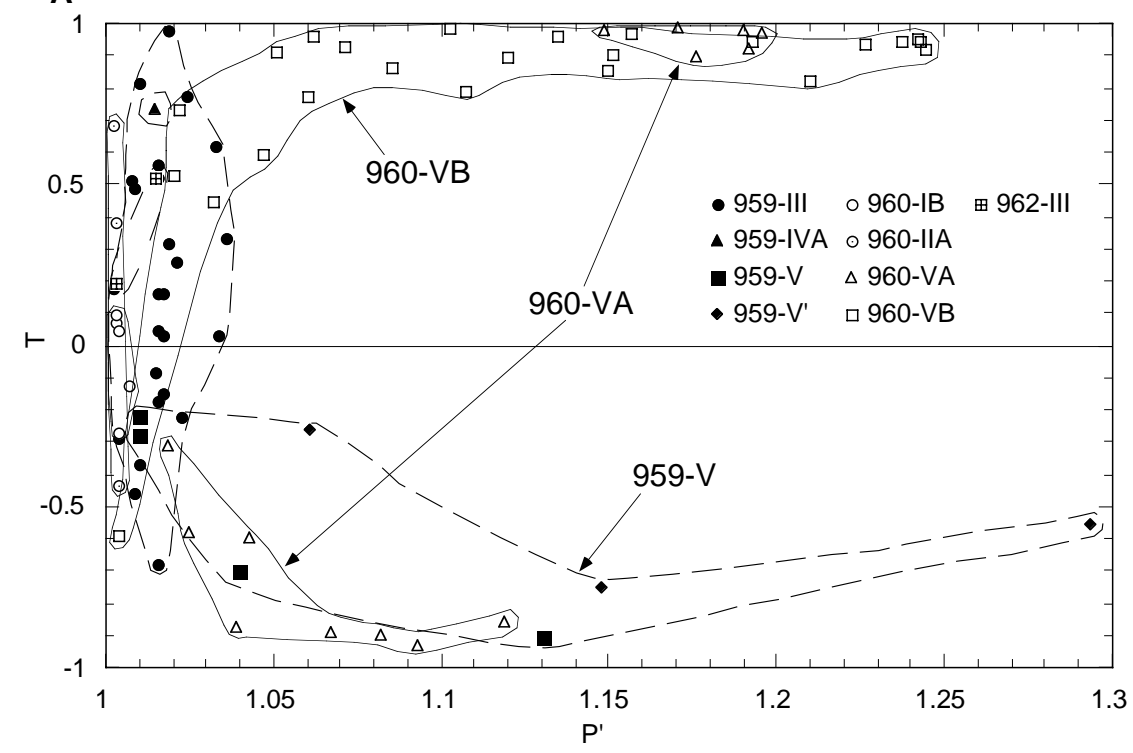

B

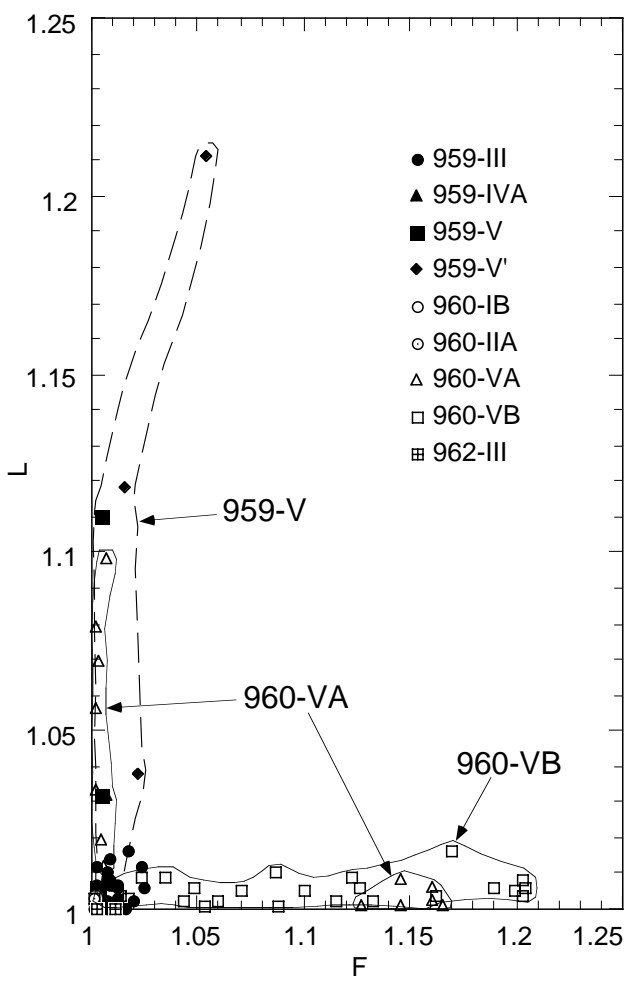

Figure 2. Results of the AMS analyses with respect to the fine-grained sediments. A. Magnetic anisotropy plot of the analyzed sediments. $\mathrm{P}^{\prime}$ indicates the degree of anisotropy, and $\mathrm{T}$ is the shape of the susceptibility ellipsoid. $\mathrm{T}=+1$ : planar magnetic fabric and uniaxial oblate ellipsoid; $\mathrm{T}=-1$ : linear magnetic fabric and uniaxial prolate ellipsoid; $\mathrm{T}>0$ : oblate ellipsoid; $\mathrm{T}<0$ : prolate ellipsoid; $\mathrm{T}=0$ : neutral or triaxial ellipsoid. B. Flinn-type plot of the degree of lineation $(\mathrm{L})$ and foliation $(\mathrm{F})$.

Type 3 is the negative $T$ value-high-anisotropy-degree type. We consider Type 3 to be unusual, as it is difficult to create an environment where the sediments of Type 3 could be produced by simple deformation or shear stresses. However, Type 3 is dominant in Unit V at Hole 959D and in the interval between 360 and 380 mbsf of Subunit VA at Hole 960A.

Figure 3 is a magnified rock photograph on the vertical-to-thebedding plane of Sample 159-960A-45R-1, 44-46 cm. It shows vertically elongated minerals, $0.3 \mathrm{~mm}$ in maximum size, that are dominated by claystone, whereas some organic materials lie along the bedding plane. XRD analysis and thin-section observation corroborate that these elongated grains are composed of siderite $\left(\mathrm{FeCO}_{3}\right.$; Fig. 4). Siderite observed microscopically shows a rhombic or rectangular shape and displays a very high double refraction and high refractive index. The XRD analysis was performed on Sample 159-960A-47R$1,65-67 \mathrm{~cm}$, after extracting the aligned minerals from claystone by crushing and ultrasonic agitation. Siderite grains were also observed in some of the other Type 3 specimens from both Holes 959D and 960A. The fact that siderite shows a vertical elongation in sediments should indicate secondary mineralization.

Samples 159-960A-44R-2, 80-82 cm, through 47R-1, 99-101 $\mathrm{cm}$, indicate consistent low angles $\left(<15^{\circ}\right)$ of the inclination of the minimum axes $\left(K_{\min } I\right)$ of the susceptibility ellipsoid (Fig. 5). There, the bedding plane dips at a rather shallow angle, between $10^{\circ}$ and $20^{\circ}$ within this interval between 364 and 378 mbsf (Fig. 5). These facts show that the sediments have a lineated magnetic fabric, which is almost perpendicular to the bedding plane. Furthermore, in Unit V at Hole $960 \mathrm{~A}$, the $K_{\min } I$ also shows a consistent low angle lying from $10^{\circ}$ to $30^{\circ}$, whereas the bedding dip shows various angles from $35^{\circ}$ to $85^{\circ}$ (Fig. 5). From these, we conclude that the lineation of magnetic fabric in Type 3 sediments is vertical with no relation to angles of bedding plane. 


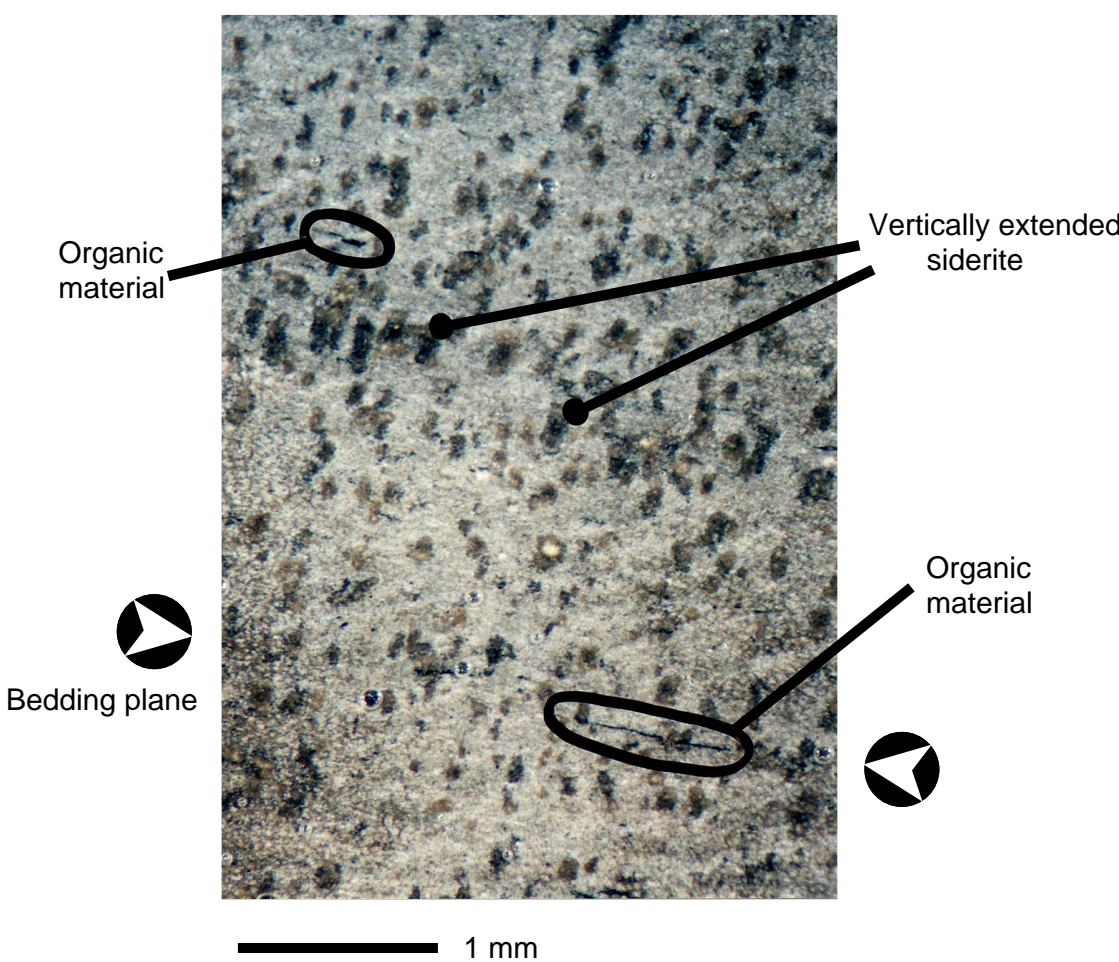

Figure 3. Magnification of claystone containing vertically aligned siderite $\left(\mathrm{FeCO}_{3}\right)$ grains. Organic material indicates the orientation of the bedding plane. Sample 159-960A-45R-1, 44-46 cm.

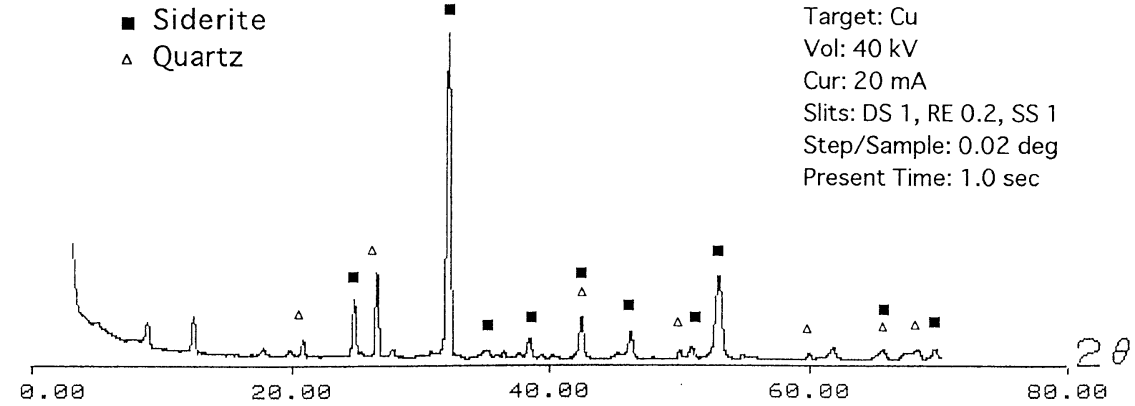

Figure 4. XRD chart of the grains extracted from a Type 3 claystone. Sample 159-960A-47R-1, 65-67 $\mathrm{cm}$.
Tarling and Hrouda (1993) state that siderite produces a high degree of magnetic anisotropy of a prolate shape. Siderite has been described only in Cores 159-960A-44R and 45R in Mascle, Lohmann, Clift, et al. (1996). However, it can be inferred that siderite may dominate in lithologic Unit V at Hole 959D and in the interval from 360 to 380 mbsf of Subunit VA at Hole 960A. Furthermore, the anisotropy of Type 3 should depend on the degree of alignment of the individual siderite grain. We interpret that the vertically aligned mineralization of siderite must have occurred secondarily, which indicates the sediments of Type 3 should have undergone syn- to postdiagenetic horizontal compressional constraint.

The three types of fabric, Type 1 (sedimentary), Type 2 (deformed sedimentary), and Type 3 (sideritic deformed sedimentary), show a disordered stratigraphic occurrence. The pebble from drillingdisturbed interval 159-959D-72R-3, 72-82 cm (1094 mbsf), in lithologic Unit V has a very high density, 2530 in CT value. This may indicate dehydration by substantial compressional deformation. In Unit $\mathrm{V}$ at Hole $960 \mathrm{~A}$, the Type 3 domain is sandwiched by Type 2 domains, and bedding planes change dip angles abruptly at their boundaries (Fig. 5). Further deformation was reported from Unit V by shipboard structural analysis. This data set suggests a possible structural break characterized by AMS zoning, dip angle variation, and intensity of fracturing, which bounds the domains by major faults. On board, because of gross similarities in lithology, these domains were not identified clearly. If this is the case, the Type 3 domain may represent a tectonic slice of faulted and/or folded sequence with aligned mineralization development.

The result of magnetic fabric analysis presented in this study shows that the syntransform sequence encountered in Leg 159 might be composed of tectonic slices of lithologic domains with various degrees of deformation and thickness juxtaposed by faults. This may have formed during the complex deformation after deposition of the present Type 3 sediments. Although the age of lithologic Unit V at Site 960 is unknown, the uppermost part of Type 3 sediments at Hole 959D (1082 mbsf) is the late Albian (Mascle, Lohmann, Clift, et al., 1996). Because this tectonic slicing ceased by the end of the uplift of the Côte d'Ivoire-Ghana Marginal Ridge, the oldest sediments overlying the unconformity of the marginal ridge emergence may be a sign of the end of the deformation. Consequently, the tectonic slicing of lithologic domains may have formed from the latest Albian to early Turonian.

\section{CONCLUSIONS}

1. The magnetic fabric analysis of fine-grained sediments, cored at the Côte d'Ivoire-Ghana Transform Margin from Holes 959D and 

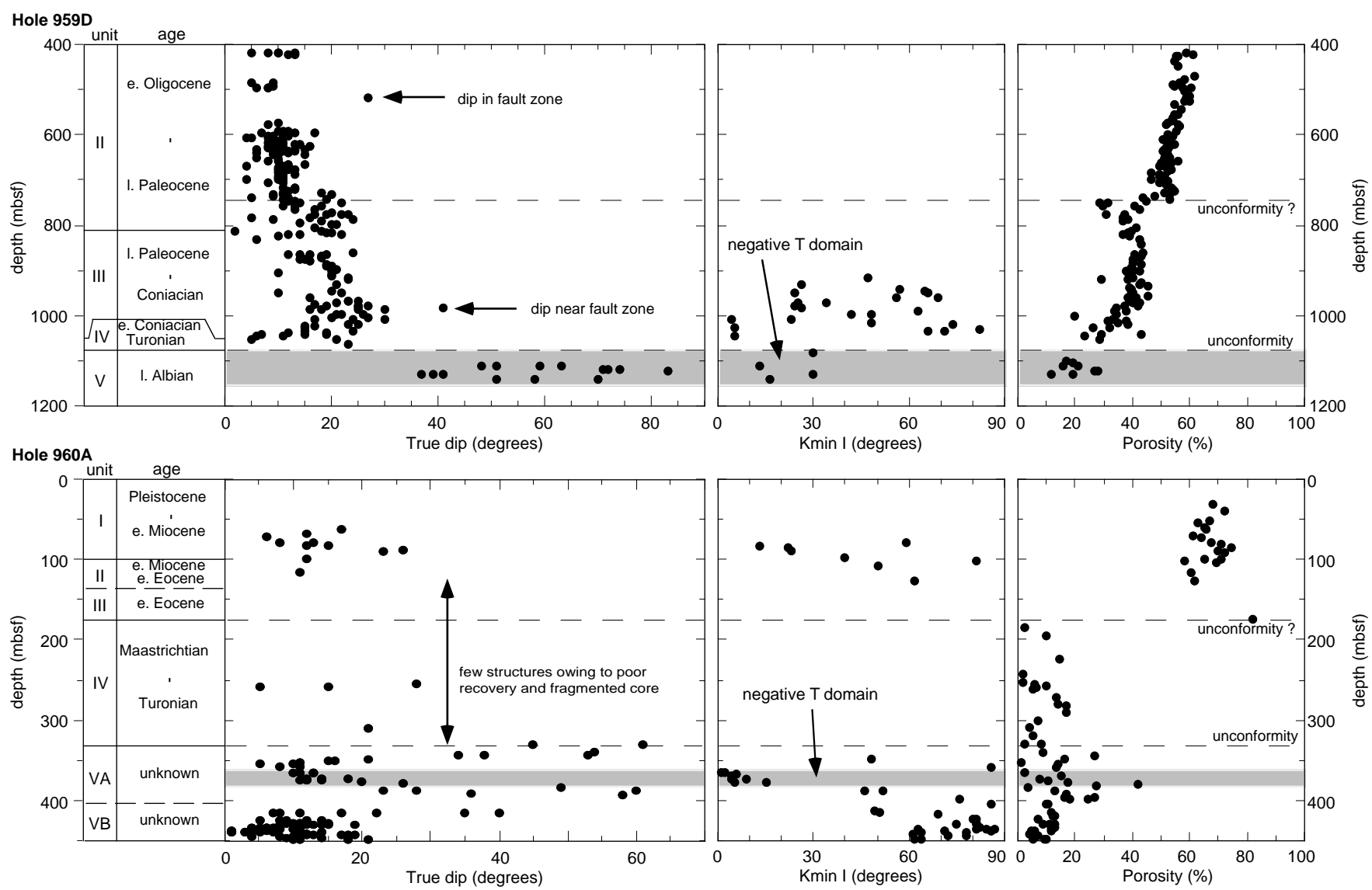

Figure 5. Downhole profiles of $K_{\min } I$ (inclination of the minimum axis of susceptibility ellipsoid) compared with bedding dip and porosity at Holes 959D and 960A. Bedding dip and porosity data were reported by Mascle, Lohmann, Clift, et al. (1996).

960A, shows positions of three types of anisotropic variation in the stratigraphic section: Type 1, a low-degree magnetic anisotropy type; Type 2, a positive $T$ value, high-degree anisotropy type; and Type 3 , a negative $T$ value, high-degree anisotropy type. The shapes of the ellipsoids of magnetic susceptibility are spheric, oblate, and prolate, respectively.

2. Negative $T$ value sediments observed in lithologic Unit $\mathrm{V}$ at Hole 959D and Subunit VA at Hole 960A display vertically linear magnetic fabric, which is controlled by secondary mineralized and vertically aligned siderite $\left(\mathrm{FeCO}_{3}\right)$ grains that produce unusual linear ellipsoids of magnetic susceptibility. The secondary mineralization of vertically aligned siderite indicates a horizontal compressional strain during the deformation at the end of the Syntransform Basin Stage.

3. The syntransform sequence might be composed of tectonic slices of lithologic domains with varying degrees of deformation, which may have formed from the latest Albian to the early Turonian.

\section{ACKNOWLEDGMENTS}

The authors would like to thank the following people for their contributions. Comments and help with AMS analyses from Dr. Juichiro Ashi at the Geological Institute, University of Tokyo, and Dr. Toshiya Kanamatsu at the Japan Marine Science and Technology Center greatly contributed to this study. CT scanning was supported by Drs. Komei Okatsu and Toshiyasu Munakata at the Technology
Research Center, JNOC. We thank the participants of the Leg 159 Shipboard Scientific Party, technicians, and crew.

\section{REFERENCES}

Anderson, S.H., Gantzer, C.J., Boone, J.M., and Tully, R.J., 1988. Rapid nondestructive bulk density and soil-water content determination by computed tomography. Soil Sci. Soc. Am. J., 52:35-40.

Ashi, J., 1995. CT scan analysis of sediments from Leg 146. In Carson, B., Westbrook, G.K., Musgrave, R.J., and Suess, E. (Eds.), Proc. ODP, Sci. Results, 146 (Pt. 1): College Station, TX (Ocean Drilling Program), 191199.

Balsley, J.R., and Buddington, A.F., 1960. Magnetic susceptibility anisotropy and fabric of some Adirondack granites and orthogneisses. Am. J. Sci., 2:6-20.

Barton, P.J., Owen, T.R.E., and White, R.S., 1990. The deep structure of the east Oman continental margin: preliminary results and interpretation. Tectonophysics, 173:319-331.

Borradaile, G.J., 1988. Magnetic susceptibility, petrofabrics and strain. Tectonophysics, 156:1-20.

Borradaile, G.J., and Tarling, D.H., 1981. The influence of deformation mechanisms on magnetic fabrics in weakly deformed rocks. Tectonophysics, 77:151-168.

Grant, A.C., 1977. Multichannel seismic reflection profiles of the continental crust beneath the Newfoundland Ridge. Nature, 270:22-25.

Iwai, Y., 1979. CT Scanner-X-ray Computed Tomography Scanner: Tokyo (Corona-sha Publ.). (in Japanese)

Jelinek, V., 1981. Characterization of the magnetic fabric of rocks. Tectonophysics, 79:63-67. 
Kanamatsu, T., 1996. A study on the magnetic fabric of the sediment in the accretionary complex, the Boso and Miura Peninsulas, central Japan [M.S. thesis]. Univ. Tokyo.

Kligfield, R., Lowrie, W., and Dalziel, I.W.D., 1977. Magnetic susceptibility anisotropy as a strain indicator in the Sudbury Basin, Ontario. Tectonophysics, 40:287-308.

Le Pichon, X., and Hayes, D.E., 1971. Marginal offsets, fracture zones and the early opening of the South Atlantic. J. Geophys. Res., 76:6283-6293.

Lorenzo, J.M., Mutter, J.C., Larson, R.L., Buhl, P., Diebold, J.B., Alsop, J., Hopper, J., Falvey, D., Williamson, P., and Brassil, F., 1991. Development of the continent-ocean transform boundary of the southern Exmouth Plateau. Geology, 19:843-846.

Mascle, J., and Blarez, E., 1987. Evidence for transform margin evolution from the Côte d'Ivoire-Ghana continental margin. Nature, 326:378-381.

Mascle, J., Lohmann, G.P., Clift, P.D., et al., 1996. Proc. ODP, Init. Repts., 159: College Station, TX (Ocean Drilling Program).

Rees, A.I., and Woodall, W.A., 1975. The magnetic fabric of some laboratory deposited sediments. Earth Planet. Sci. Lett., 25:121-130.

Sagnotti, L., Faccenna, C., Funiciello, R., and Mattei, M., 1994. Magnetic fabric and structural setting of Plio-Pleistocene clayey units in an extensional regime: the Tyrrhenian margin of central Italy. J. Struct. Geol., $16: 1243-1257$.
Sagnotti, L., and Speranza, F., 1993. Magnetic fabric analysis of the PlioPleistocene clayey units of the Sant' Arcangelo basin, south Italy. Phys. Earth Planet. Inter., 77:165-176.

Soh, W., Byrne, T., Taira, A., and Kono, A., 1993. Computed tomography (CT) scan image analysis of Site 808 cores: structural and physical property implications. In Hill, I.A., Taira, A., Firth, J.V., et al., Proc. ODP, Sci. Results, 131: College Station, TX (Ocean Drilling Program), 135140.

Stacey, F.D., Joplin, G., and Lindsay, J., 1960. Magnetic anisotropy and fabric of some foliated rocks from S.E. Australia. Geofis. Pura Appl., 47:3040.

Taira, A., 1989. Magnetic fabrics and depositional processes. In Taira, A., and Masuda, F. (Eds.), Sedimentary Facies in the Active Plate Margin: Tokyo (Terra Sci. Publ.), 43-77.

Tarling, D.H., and Hrouda, F., 1993. The Magnetic Anisotropy of Rocks: London (Chapman and Hall).

Date of initial receipt: 30 September 1996

Date of acceptance: 16 May 1997

Ms 159SR-042 